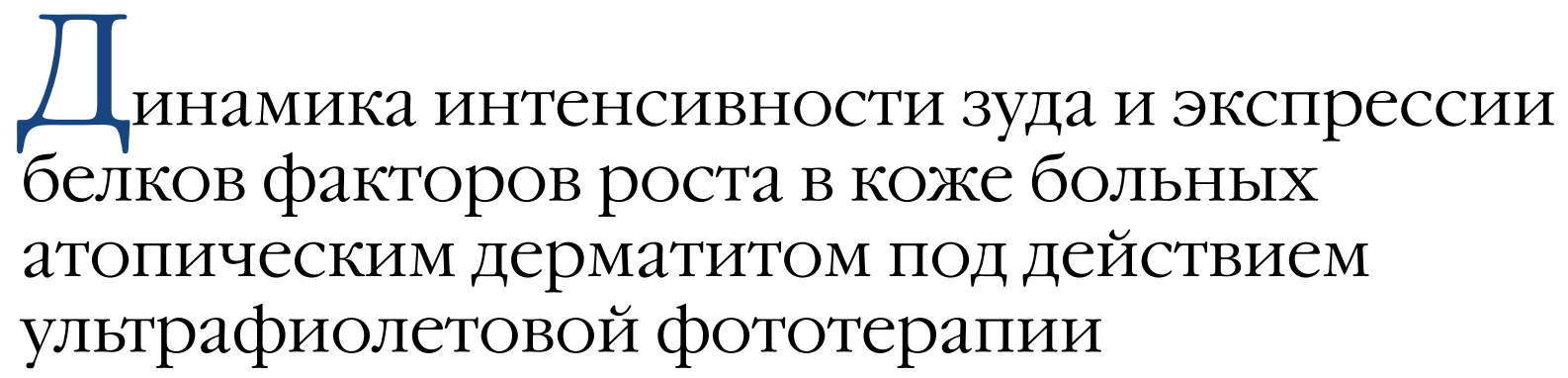

\author{
А.А. Кубанова ${ }^{1}$, А.А. Кубанов ${ }^{1}$, В.В. Чикин ${ }^{1}$, В.А. Волнухинн ${ }^{1}$, В.А. Смольянникова ${ }^{2}$, \\ М.А. Нефедова ${ }^{1}$
}

1 ФГБУ «Государственный научный центр дерматовенерологии и косметологии» Минздрава России 107076, Москва, ул. Короленко, д. 3, стр. 6

2 ГБОУ ВПО «Первый Московский государственный медицинский университет имени И.М. Сеченова» Минздрава России

119991, Москва, ул. Малая Трубецкая, д. 8, стр. 1

Цель. Изучение динамики интенсивности зуда и уровня экспрессии в коже больных атопическим дерматитом белков факторов роста под действием узкополосной (311 нм) фрототерапии.

Материал и методы. 30 больным атопическим дерматитом проводили лечение методом узкополосной (311 нм) фототерапии. Для оценки тяжести клинических проявлений использовали индекс SCORAD. Интенсивность зуда определяли с использованием визуальной аналоговой шкалы. Экспрессию в коже фактора роста нервов, семафорина-3А, амфирегулина и маркера нервных волокон белка PGP9.5 исследовали методом непрямой иммунослюоресценции.

Результаты. В эпидермисе больных обнаружены повышенный уровень экспрессии фрактора роста нервов и сниженный уровень экспрессии семафорина-ЗА, а также увеличение количества, средней длины и интенсивности свечения PGP9.5+-нервных волокон. Проведение курса узкополосной (311 нм) фототерапии привело к снижению степени тяжести заболевания и интенсивности зуда, что сопровождалось снижением экспрессии фактора роста нервов и повышением экспрессии семафорина-ЗА, уменьшением количества и средней длины нервных волокон в эпидермисе. Выявлены прямая корреляционная связь между интенсивностью зуда и уровнем экспрессии фрактора роста нервов, количеством и средней длиной PGP9.5+-нервных волокон в эпидермисе, а также обратная корреляционная связь между интенсивностью зуда и уровнем экспрессии семафорина-ЗА в эпидермисе.

Заключение. Проведение курса узкополосной (311 нм) фототерапии больным атопическим дерматитом приводит к уменьшению интенсивности зуда, ассоциированному со снижением выраженности иннервации эпидермиса. Уменьшению иннервации эпидермиса при проведении фототерапии способствуют снижение уровня экспрессии срактора роста нервов и повышение экспрессии семафорина-3А.

Ключевые слова: атопический дерматит, зуд, фактор роста нервов, семафорин-3А, амфирегулин, нервы кожи, белок PGP9.5. 


\title{
Progression of itching intensity and expression of growth factor proteins in skin of people suffering from atopic dermatitis under the influence of ultraviolet phototherapy
}

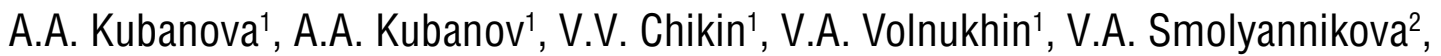 \\ M.A. Nefedova ${ }^{1}$
}

${ }^{1}$ State Research Center of Dermatovenereology and Cosmetology, Ministry of Healthcare of the Russian Federation Korolenko str., 3, bldg 6, Moscow, 107076, Russia

${ }^{2}$ I.M. Sechenov First Moskow State Medical University

M. Trubetskaya str., 8, bldg 1, Moscow, 119991, Russia

\begin{abstract}
Study of progression of itching intensity and expression of growth factor proteins in skin of people suffering from atopic dermatitis under the influence of narrowband (311 Nm) phototherapy.

Material and methods. 30 patients with atopic dermatitis were treated by using narrowband $(311 \mathrm{Nm})$ phototherapy. SCORAD index was used to assess the severity of the clinical responses. Itching intensity was assessed using visual analogue scale. Expression of growth factor of nerves, semaphorine-3A, amphiregulin, and PGP9.5, a protein marker for nerve fibers, was investigated by means of indirect immunofluorescence.

Results. Increased expression level of nerves growth factor, decreased expression level of semaphorine-3A, and increase in the number, average length and luminous intensity of PGP9.5+ -nerve fibers were found in the patients' epidermis. Course of narrowband $(311 \mathrm{Nm})$ phototherapy resulted in a decrease of the severity of the disease and itching intensity, and semaphorine-3A expression increase, reduction of number and average length of nerve fibers in the epidermis. A direct correlation relationship between the itching intensity and expression level of nerve growth factor, number and average length of PGP9.5+ -nerve fibers in the epidermis as well as an inverse correlation relationship between itching intensity and expression level of semaphorine-3A in the epidermis were found.

Conclusion. Treating patients suffering from atopic dermatitis with narrowband (311 Nm) phototherapy leads to a decrease of the itching intensity associated with a decreased intensity of innervation of the epidermis. This decrease in course of phototherapy is facilitated by decrease of nerve growth factor expression level and increase of semaphorine-3A expression.
\end{abstract}

Key words: atopic dermatitis, itching, nerve growth factor, semaphorine-3A, amphiregulin, skin nerves, PGP9.5 protein.

Corresponding author: info@cnikvi.ru. Vestnik Dermatologii i Venerologii 2015; 5: 59—65.

Атопический дерматит (АтД) - одно из наиболее распространенных хронических воспалительных заболеваний кожи. В 2014 г. заболеваемость АтД в Российской Федерации составила 230,2 на 100000 населения, а его распространенность - 443,3 на 100000 населения. Одним из основных проявлений заболевания является зуд, при отсутствии которого диагноз АтД считается сомнительным. Зуд относится к факторам, наиболее сильно снижающим качество жизни больных АтД. Расчесывание, провоцируемое зудом, у больных АтД не ослабляет зуд, а приводит к его усилению и ухудшению состояния кожи в очагах пораже- ния. Поэтому уменьшение зуда считается необходимым условием для улучшения состояния кожи и повышения качества жизни больных [1].

Для лечения зуда применяются $\mathrm{H}_{1}$-антигистаминные препараты, однако в терапии больных АтД их эффрективность часто бывает недостаточна. Это обусловлено негистаминергическими механизмами развития зуда, в которых принимают участие протеазы, цитокины, нейропептиды. В последние годы показано, что важная роль в патогенезе зуда принадлежит иннервации кожи. Усилением иннервации эпидермиса может быть обусловлена резистентность зуда к анти- 
гистаминным препаратам. Выраженность иннервации кожи определяется балансом между факторами, способствующими росту нервных волокон и ингибирующими этот процесс [2]. Росту нервных волокон способствуют нейротрофины, к которым относится фактор роста нервов, и эпидермальный фрактор роста амфирегулин [3, 4]. Их антагонистом является фрактор редукции нервов семафорин-ЗА, который участвует в процессах уменьшения выраженности иннервации, отклоняя конус роста нерва [5].

В экспериментах на мышах показана возможность уменьшения роста нервных волокон при облучении кожи узкополосным средневолновым ультрафиолетовым излучением с длиной волны 311 нм [6]. Данный вид излучения применяется в клинической практике для лечения различных дерматозов, в том числе атопического дерматита. Установлено ингибирующее действие фототерапии на характерную для этого заболевания воспалительную реакцию, реализуемую в коже Th2- и Т22-лимфоцитами [7]. Под действием узкополосной (311 нм) фрототерапии не только уменьшаются кожные проявления при АтД, но и снижается интенсивность зуда [8, 9]. Предполагается, что противозудный эффрект фототерапии обусловлен не только подавлением воспалительной реакции, но и ее способностью воздействовать на механизмы развития зуда [10].

Целью нашей работы явилось изучение динамики интенсивности зуда и уровня экспрессии в коже больных атопическим дерматитом белков фракторов роста под действием узкополосной (311 нм) фрототерапии.

\section{Материал и методы}

Под наблюдением находились 30 больных АтД 16 женщин и 14 мужчин в возрасте от 18 до 43 лет. Диагноз АтД был подтвержден патоморфологическими исследованиями. Степень тяжести заболевания определяли с помощью индекса SCORAD. АтД считали тяжелым, если индекс SCORAD составлял более 40 баллов, средней тяжести, если индекс SCORAD составлял от 20 до 40 баллов. Интенсивность зуда определялась больными с помощью визуальной аналоговой шкалы (от 0 до 10 баллов). Слабый зуд соответствовал 1-3 баллам, умеренный - 4-7 баллам, выраженный - 8-10 баллам.

Всем больным АтД проводили курс узкополосной (311 нм) фототерапии с использованием ультрафиолетовой кабины Waldmann UV 7001K Herbert Waldmann $\mathrm{GmbH} \& \mathrm{Co}$. KG (Германия), укомплектованной лампами TL-01, излучающими в диапазоне 310-315 нм с максимумом эмиссии на длине волны 311 нм. Начальные дозы облучения варьировали от 0,15 до 0,39 Дж/см². Процедуры проводили с режимом 4 раза в неделю, каждую процедуру разовую дозу увеличивали на $10-20 \%$.
До и после лечения в коже больных методом непрямой иммунофлюоресценции исследовали экспрессию нейротрофина фактора роста нервов, эпидермального фактора роста амфирегулина, фактора редукции нервов семафорина-ЗА и маркера нервных волокон белка PGP9.5. Исследования проводили на криостатных срезах по ранее разработанному протоколу [11].

Для определения уровня экспрессии указанных биомаркеров использовали метод конфокальной микроскопии ex vivo. Готовые препараты изучали с использованием конфокального лазерного сканирующего микроскопа Olympus IX81S1F-S (Германия) (объективы $\times 200$ и ×600), оснащенного фоотомикрографической системой, и персонального компьютера с программным обеспечением Olympus Fluoview Ver. 1.7b. Экспрессию фактора роста нервов, амфирегулина, семафорина-3А и белка PGP9.5 выражали в виде средних значений интенсивности свечения по заданному каналу в условных единицах (усл. ед.). Экспрессия маркера нервных волокон белка PGP9.5 также позволила определить количество и среднюю длину нервных волокон в эпидермисе, на границе эпидермиса и дермы и в дерме (исследовались по 3 поля зрения для каждого биоптата).

Контрольную группу составили 25 здоровых лиц.

Статистический анализ полученных данных проводили с помощью программы Statistica 10. Для сравнения показателей в группах использовали критерий Манна - Уитни. Для сравнения показателей, полученных при обследовании больных до и после лечения, применяли критерий Уилкоксона. Данные представляли в виде $M \pm \sigma$. Наличие корреляционных связей выявляли с помощью рангового коэффрициента корреляции Спирмена. Различия считали достоверными при уровне статистической значимости $p<0,05$.

\section{Результаты}

До лечения величина индекса SCORAD варьировала от 29,9 до 82,7, в среднем 52,4 $\pm 12,5$ балла. У 23 $(76,7 \%)$ больных был диагностирован тяжелый атопический дерматит, у 7 (23,3\%) - атопический дерматит средней тяжести. Интенсивность зуда составляла от 2 до 10 баллов, в среднем 7,9 $\pm 2,2$ балла. У 20 (66,7\%) больных интенсивность зуда была выраженной, у 8 $(26,7 \%)$ - умеренной, у $2(6,66 \%)$ - слабой.

На курс узкополосной (311 нм) фоототерапии назначали 16 процедур. Максимальная доза облучения варьировала от 0,3 до 1,37 Дж/см². Курсовая доза об-

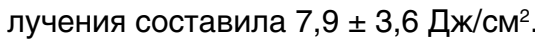

После терапии индекс SCORAD у больных варьировал от 3,9 до 35,6 балла. Проведение курса фрототерапии привело к статистически значимому уменьшению индекса SCORAD с 52,4 $\pm 12,5$ до 15,4 \pm 8,2 балла $(p<0,05)$. Интенсивность зуда в результате лечения статистически значимо уменьшилась с 7,9 $\pm 2,2$ до $1,7 \pm 1,6$ балла $(p<0,05)$. После фототерапии зуд 
отсутствовал у 10 (33,33\%) больных, на слабый зуд жаловались 16 (53,34\%) больных, на умеренный зуд $4(13,33 \%)$ пациента.

При исследовании кожи методом непрямой иммунофлюоресценции фактор роста нервов обнаруживался в цитоплазме кератиноцитов, в эпителиоцитах наружного и внутреннего эпителиального влагалища волосяных фолликулов, а также в эпителиальных клетках потовых желез (рис. 1). В этих же структурах кожи наблюдали экспрессию амфирегулина. Экспрессия семафорина-ЗА была выявлена в цитоплазме кератиноцитов преимущественно в базальном и супрабазальных слоях эпидермиса (рис. 2).

При статистическом анализе установлен более высокий уровень экспрессии фактора роста нервов в эпидермисе больных АтД по сравнению с контрольной группой (на 41,3\%, $p<0,001)$ и пониженный уровень экспрессии семафорина-ЗА по сравнению с контрольной группой (на 33,8\%, $p<0,001$ ) (табл. 1). Уровень экспрессии амфирегулина у больных не отличался от контрольной группы.

Свечение белка PGP9.5 наблюдалось на нервных волокнах, присутствующих рядом с потовыми железами, в составе сосудисто-нервных пучков, между гладкомышечными пучками мышцы, поднимающей волос, и в нервных стволиках, расположенных в дерме. Кроме того, тонкие PGP9.5+-нервные волокна обнаруживались в сосочковом слое дермы. У всех больных тонкие PGP9.5+-нервные волокна располагались также в эпидермисе (рис. 3).

При подсчете количества PGP9.5+-нервных волокон в коже больных выявлено повышенное по сравнению с контрольной группой содержание нервных волокон в эпидермисе - в 6,8 раз ( $p<0,001)$ (табл. 2).
Кроме того, средняя длина PGP9.5+-нервных волокон в эпидермисе больных оказалась в 2,3 раза больше, чем в контрольной группе $(p=0,01)$. В эпидермисе больных была также выявлена более высокая средняя интенсивность свечения PGP9.5+-нервных волокон по сравнению с контрольной группой $(p=0,01)$.

После лечения обнаружено уменьшение уровня экспрессии фрактора роста нервов (на 33,3\%) и увеличение уровня экспрессии семафорина-3А (на 74,1\%). Различия уровня экспрессии фактора роста нервов и семафорина-ЗА в эпидермисе больных до и после лечения были статистически значимы $(p<0,001)$ (см. табл. 1). Экспрессия амфирегулина после терапии не подвергалась значимой динамике.

Нами было обнаружено нормализующее действие фототерапии на количество PGP9.5+-нервных волокон в эпидермисе в коже больных: в эпидермисе оно уменьшилось на $41,4 \%(p=0,003)$ и в дерме на $38,1 \%$ $(p<0,001)$. Средняя длина PGP9.5+-нервных волокон после лечения больных методом узкополосной (311 нм) фототерапии уменьшилась в эпидермисе на $30,9 \%(p=0,0012)$ и в дерме на 29,6\% $(p<0,001)$. Средняя интенсивность свечения PGP9.5+-нервных волокон в эпидермисе больных уменьшилась после лечения на $14,6 \%(p=0,043)$.

Корреляционный анализ показателей выявил наличие сильной прямой корреляционной связи между величиной индекса SCORAD и интенсивностью зуда $(r=0,863 ; p=0,000)$. Обнаружена прямая корреляционная связь интенсивности зуда с уровнем экспрессии в эпидермисе фрактора роста нервов ( $r=0,757$; $p=0,000)$ и обратная корреляционная связь между интенсивностью зуда и уровнем экспрессии в эпидермисе фрактора редукции нервов семафорина-ЗА

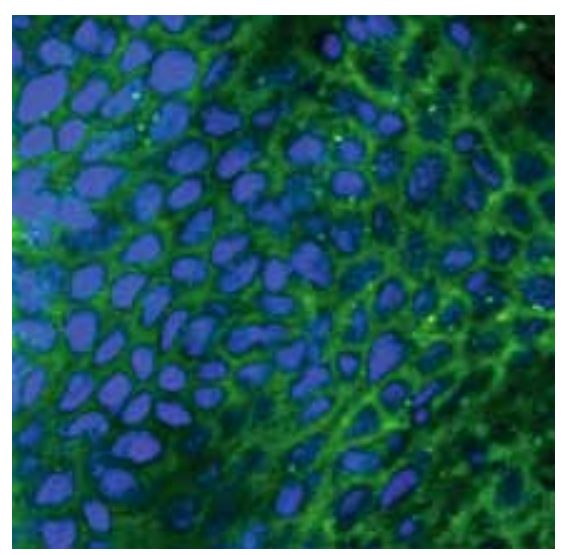

$a$

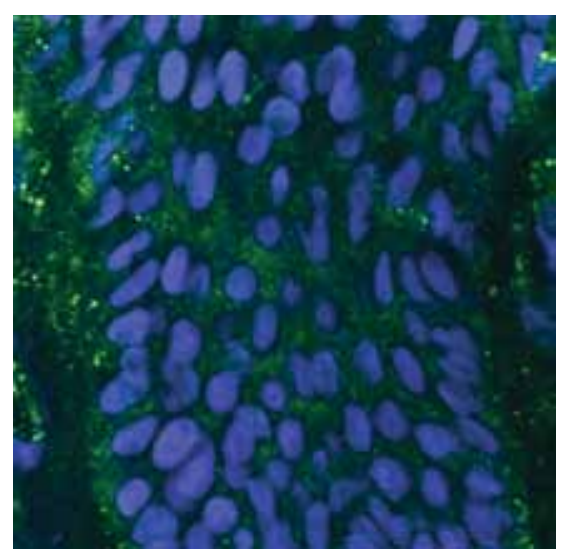

6

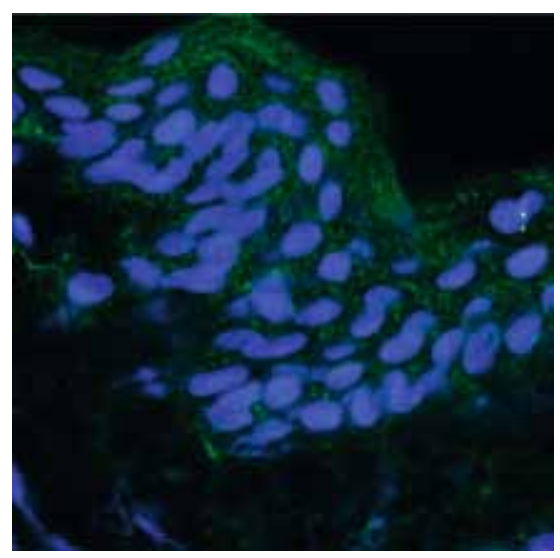

$B$

Рис 1. Экспрессия фактора роста нервов (зеленое свечение) в эпидермисе: а и б - у больного атопическим дерматитом до и после узкополосной (311 нм) фототерапии соответственно; в - у здорового человека. Непрямая иммунофлюоресценция, ×600 


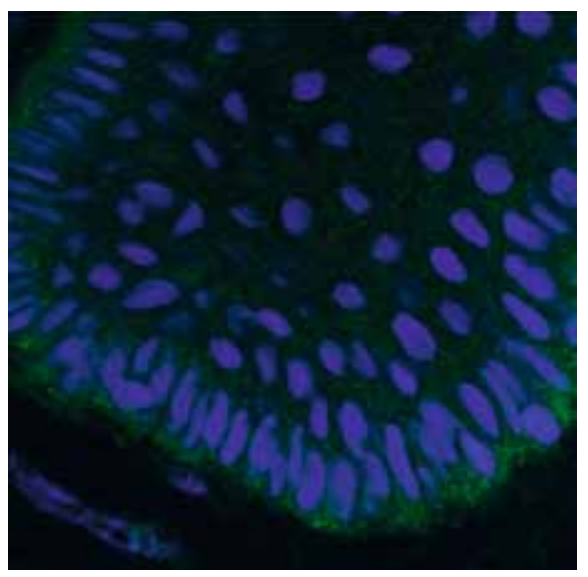

a

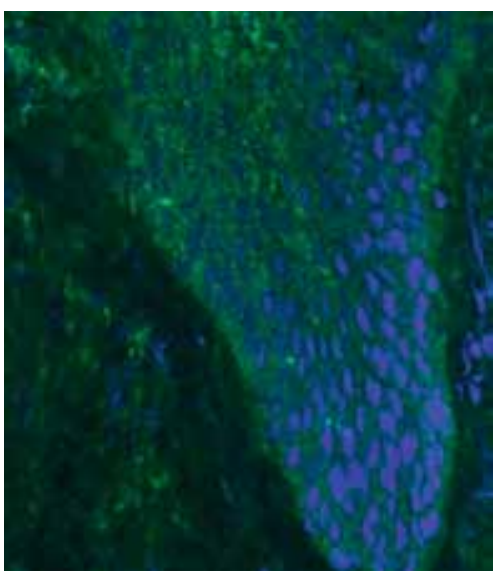

$\sigma$

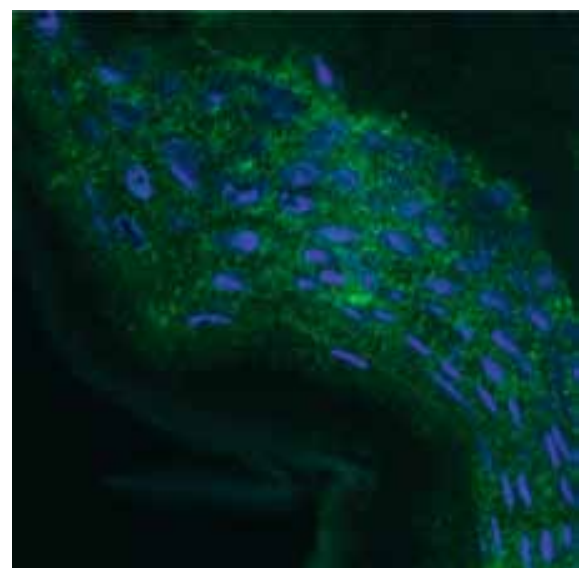

$B$

Рис 2. Экспрессия семафорина-ЗА (зеленое свечение) в эпидермисе: а и $\sigma-$ у больного атопическим дерматитом до и после узкополосной (311 нм) фототерапии соответственно; $в-$ у здорового человека. Непрямая иммунофрлюоресценция, $\times 600$

$\begin{array}{ll}\text { Таблица } 1 & \text { Уровень экспрессии белков фракторов роста в коже больных атопическим дерматитом, усл. ед. } \\ (\mathrm{M} \pm \sigma)\end{array}$

\begin{tabular}{|c|c|c|c|}
\hline \multirow{2}{*}{ Показатель } & \multirow{2}{*}{ Контрольная группа ( $n=25)$} & \multicolumn{2}{|c|}{ Больные атопическим дерматитом $(n=30)$} \\
\hline & & до лечения & после лечения \\
\hline Фактор роста нервов & $485,5 \pm 109,2$ & $685,9 \pm 153,2^{*}$ & $457,2 \pm 173,1^{\text {* * }}$ \\
\hline Семафрорин-ЗА & $178,3 \pm 75,3$ & $118,1 \pm 38,1^{*}$ & $205,6 \pm 67,6^{\star *}$ \\
\hline Амфирегулин & $109,9 \pm 78,1$ & $112,6 \pm 64,1$ & $98,8 \pm 36,1$ \\
\hline
\end{tabular}

Примечание. * — статистически значимые различия между группой больных и контрольной группой; ** — статистически значимые различия в группе больных до и после лечения.

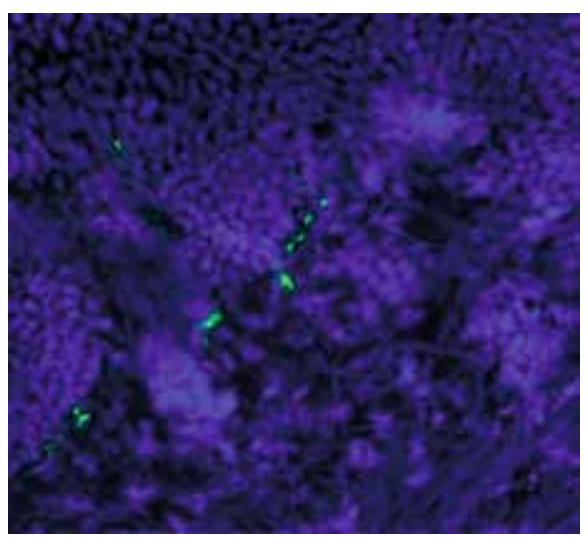

a

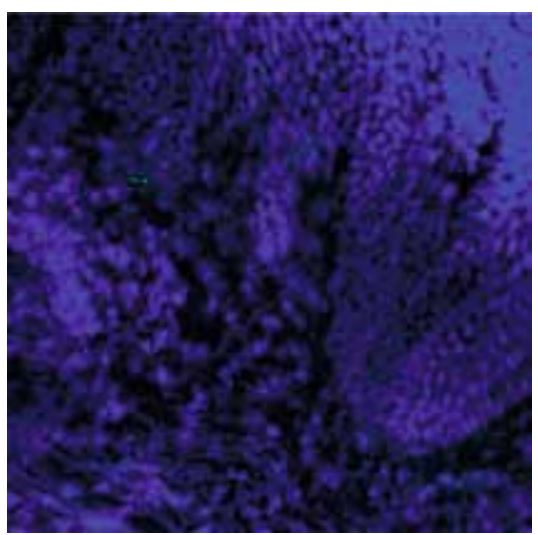

б

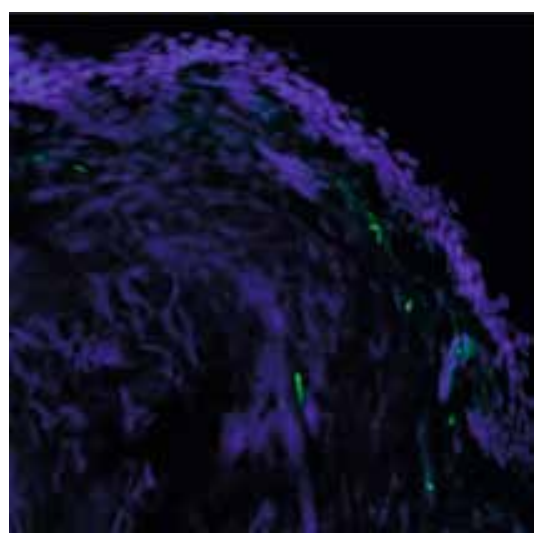

$B$

Рис. 3. Нервные волокна (зеленое свечение) в эпидермисе и дерме: а и б - у больного атопическим дерматитом до и после узкополосной (311 нм) фототерапии соответственно; в - у здорового человека. Непрямая иммунофрлюоресценция, $\times 200$ 
Таблица 2

Показатели иннервации кожи у больных атопическим дерматитом $(\mathrm{M} \pm \sigma)$

\begin{tabular}{lccc}
\hline \multirow{2}{*}{ Показатель } & Контрольная группа & Больные атопическим дерматитом $(n=30)$ \\
\cline { 2 - 4 } & $(n=25)$ & до лечения & после лечения \\
\hline Количество нервных волокон в эпидермисе & $1,0 \pm 1,8$ & $6,8 \pm 3,4^{*}$ & $4,0 \pm 3,5^{\star *}$ \\
\hline Количество нервных волокон на границе эпидермиса и дермы & $6,8 \pm 6,9$ & $8,2 \pm 4,9$ & $6,9 \pm 4,3$ \\
\hline Количество нервных волокон в дерме & $13,6 \pm 12,1$ & $18,0 \pm 8,7$ & $11,1 \pm 6,0^{* *}$ \\
\hline Средняя длина нервных волокон в эпидермисе, нм & $9,1 \pm 14,3$ & $20,9 \pm 8,1^{*}$ & $14,4 \pm 9,0^{* *}$ \\
\hline Средняя длина нервных волокон на границе эпидермиса и дермы, нм & $20,9 \pm 14,8$ & $23,2 \pm 7,9$ & $21,0 \pm 9,6$ \\
\hline Средняя длина нервных волокон в дерме, нм & $21,8 \pm 7,3$ & $27,2 \pm 11,9$ & $19,1 \pm 7,6^{* *}$ \\
\hline $\begin{array}{l}\text { Средняя интенсивность свечения нервных волокон в эпидермисе, } \\
\text { усл. ед. }\end{array}$ & $548,1 \pm 696,0$ & $1077 \pm 290,8^{*}$ & $920 \pm 345,8^{* *}$ \\
\hline $\begin{array}{l}\text { Средняя интенсивность свечения нервных волокон на границе } \\
\text { эпидермиса и дермы, усл. ед. }\end{array}$ & $1146 \pm 515,4$ & $1154 \pm 203,3$ & $1107 \pm 239,5$ \\
\hline Средняя интенсивность свечения нервных волокон в дерме, усл. ед. & $1267 \pm 267,4$ & $1231 \pm 173,6$ & $1158 \pm 247,0$ \\
\hline
\end{tabular}

Примечание. * - статистически значимые различия между группой больных и контрольной группой; ** — статистически значимые различия в группе больных до и после лечения.

$(r=-0,439 ; p=0,015)$. Корреляций между интенсивностью зуда и уровнем экспрессии амфрирегулина в эпидермисе не обнаружено.

Выявлена прямая корреляционная связь между интенсивностью зуда и количеством $(r=0,717 ; p=0,000)$, средней длиной $(r=0,622 ; p=0,0002)$ и средней интенсивностью свечения PGP9.5 $5^{+}$-нервных волокон $(r=0,609 ; p=0,0004)$ в эпидермисе. Установлена сильная прямая корреляционная связь между уровнем экспрессии фрактора роста нервов в эпидермисе и количеством $(r=0,779 ; p=0,000)$, длиной $(r=0,654 ; p=0,000)$ и средней интенсивностью свечения PGP9.5+-нервных волокон $(r=0,657 ; p=0,000)$ в эпидермисе, а также обратная корреляционная связь между уровнем экспрессии в эпидермисе семафорина-ЗА и количеством $(r=-0,602 ; p=0,0004)$, длиной $(r=-0,474 ; p=0,008)$, средней интенсивностью свечения PGP9.5+-нервных волокон в эпидермисе $(r=-0,430 ; p=0,017)$.

\section{Обсуждение}

Согласно полученным нами данным, в эпидермисе больных АтД имеется повышенная экспрессия фактора роста нервов и сниженная экспрессия семафоринаЗА, что сопровождается увеличением выраженности иннервации эпидермиса. Полученные данные согласуются с результатами других исследований, также обнаруживших повышенную иннервацию эпидермиса у больных АтД [12].

Выявленные корреляционные связи между интенсивностью зуда у больных и уровнем экспрессии как фактора роста нервов, так и семафорина-3А, свидетельствуют о патогенетическом значении изменений уровня экспрессии фактора роста нервов и семафрорина-ЗА в эпидермисе больных АтД. Изменения продукции этих фракторов в эпидермисе могут способствовать стимуляции роста нервных волокон и прорастанию их в эпидермис [13, 14]. Это подтверждается выявленными корреляционными связями между уровнями экспрессии фактора роста нервов и семафорина-ЗА и показателями иннервации эпидермиса - количеством, средней длиной и средней интенсивностью свечения $\mathrm{PGP}^{+}$-нервных волокон, а также обнаружением корреляционной связи между интенсивностью зуда и показателями иннервации эпидермиса. Полагают также, что возникновение зуда может быть связано со способностью фактора роста нервов повышать чувствительность окончаний пруритоцептивных нервов к действию медиаторов зуда [15].

Считается, что уменьшение выраженности иннервации эпидермиса может приводить к уменьшению зуда [15]. Нами обнаружено, что уменьшение интенсивности зуда, наблюдавшееся у больных атопическим дерматитом после курса узкополосной (311 нм) фрототерапии, сопровождалось уменьшением количества, средней длины и средней интенсивности свечения нервных волокон в эпидермисе. Снижению выраженности иннервации эпидермиса больных после курса лечения могло способствовать выявленное нами уменьшение уровня экспрессии фактора роста нервов и повышение экспрессии фактора редукции нервов семафорина-3А.

Полученные нами данные не выявили взаимосвязи уровня экспрессии амфирегулина с показателями иннервации эпидермиса, а также влияния на нее узкополосной (311 нм) фоототерапии. 


\section{Заключение}

Таким образом, узкополосная (311 нм) фототерапия является эфффективным средством воздействия на зуд. Установленный нами противозудный эфффект узкополосной (311 нм) фоототерапии ассоциировался как со снижением степени выраженности клинических проявлений заболевания, так и с уменьшением уровня экспрессии фактора роста нервов, а также с повышением уровня экспрессии семафорина-ЗА. Выявленная прямая корреляционная связь между интенсивностью зуда и уровнем экспрессии фрактора роста нервов, а также обратная корреляционная связь между интенсивностью зуда и уровнем экспрессии семафорина-ЗА свидетельствуют об участии этих фракторов в развитии зуда.
Повышение содержания фрактора роста нервов и снижение уровня в коже семафорина-ЗА могут способствовать росту нервных волокон и обусловливать их проникновение в эпидермис. Обнаруженная прямая корреляционная связь между интенсивностью зуда и количеством, средней длиной и средней интенсивностью свечения PGP9.5+-нервных волокон в эпидермисе указывает на патогенетическую роль иннервации эпидермиса в развитии зуда. Влияние узкополосной (311 нм) фототерапии на интенсивность зуда может быть связано с ее способностью уменьшать экспрессию фактора роста нервов и повышать экспрессию фрактора редукции нервов семафорина-ЗА, что способствует уменьшению выраженности иннервации эпидермиса. I

\section{Литература}

1. Koblenzer C.S. Itching and the atopic skin. J Allergy Clin Immunol. 1999; 104: S109-S113.

2. Tominaga M., Takamori K. An update on peripheral mechanisms and treatments of itch. Biol Pharm Bull. 2013; 36 (8): 1241-1247.

3. Albers K.M., Wright D.E., Davis B.M. Overexpression of nerve growth factor in epidermis of transgenic mice causes hypertrophy of the peripheral nervous system. J Neurosci. 1994; 14: 1422—1432.

4. Nilsson A., Kanje M. Amphiregulin acts as an autocrine survival factor for adult sensory neurons. Neuroreport. 2005; 16: 213-218.

5. Dontchev V.D., Letourneau P.C. Nerve growth factor and semaphorin $3 \mathrm{~A}$ signaling pathways interact in regulating sensory neuronal growth cone motility. J Neurosci. 2002; 22: 6659—6669.

6. Kamo A., Tominaga M., Tengara S. et al. Inhibitory effects of UV-based therapy on dry skin-inducible nerve growth in acetone-treated mice. J Dermatol Sci. 2011; 62: 91—97.
7. Tintle S., Shemer A., Suarez-Farinaz M. et al. Reversal of atopic dermatitis with narrow-band UVB phototherapy and biomarkers for therapeutic response. J Allergy Clin Immunol. 2011; 128 (3): 583-593.

8. Reynolds N.J., Franklin V., Gray J.C. et al. Narrowband ultraviolet $B$ and broad-band ultraviolet $\mathrm{A}$ phototherapy in adult atopic eczema: a randomised controlled trial. Lancet. 2001; 357: 2012—2016.

9. Gambichler T., Othlinghaus N., Tomi N.S. et al. Medium-dose ultraviolet (UV) A1 vs. narrowband UVB phototherapy in atopic eczema: a randomized crossover study. Br J Dermatol. 2009; 160: 652—658.

10. Wallengren J., Sundler F. Phototherapy reduces the number of epidermal and CGRP-positive dermal nerve fibers. Acta Derm Venereol. 2004; 84 (2): 111—115.

11. Katunina O.R., Chikin V.V., Znamenskaya L.F., Inoyatova L.A. Role of neuromediators in the development of skin irritation in patients with atopic dermatitis. Vestnik Dermatologii i Venerologii 2013; (5): 91_101. [Катунина 0.Р., Чикин В.В.,
Знаменская Л.Ф., Иноятова Л.А. Роль нейромедиаторов в развитии воспаления в коже больных атопическим дерматитом. Вестн дерматол венерол 2013; (5): 91—101].

12. Emtestam L., Hagströmer L., Dou Y.C. et al. PGP9.5 distribution patterns in biopsies from early lesions of atopic dermatitis. Arch Dermatol Res. 2012; 304 (10): 781-785.

13. Tominaga M, Ogawa H, Takamori K. Decreased production of semaphorin $3 \mathrm{~A}$ in the lesional skin of atopic dermatitis. Br J Dermatol. 2008; 158: 842-844.

14. Yamaguchi J., Aihara M., Kobayashi Y. et al. Quantitative analysis of nerve growth factor (NGF) in the atopic dermatitis and psoriasis horny layer and effect of treatment on NGF in atopic dermatitis. J Dermatol Sci. 2009; 53 (1): 48- 54 .

15. Tominaga M., Takamori K. Itch and nerve fibers with special reference to atopic dermatitis: therapeutic implications. J Dermatol. 2014; 41: 205-212.

об авторах:

А.А. Кубанова — д.м.Н., профессор, академик РАН, директор ФГБУ «ГНЦДК» Минздрава России, Москва

А.А. Кубанов - д.м.Н., профессор, зам. директора по научной работе ФГБУ «ГНЦДК» Минздрава России, Москва

В.В. Чикин — К.М.Н., старший научный сотрудник отдела дерматологии ФГБУ «ГНЦДК» Минздрава России, Москва

В.А. Волнухин - д.м.н., ведущий научный сотрудник отдела дерматологии ФГБУ «ГНЦДК» Минздрава России, Москва

В.А. Смольянникова - д.м.Н., профессор кафедры патологической анатомии ГБОУ ВПО Первый МГМУ им. И.М. Сеченова

Минздрава России, Москва

М.А. Нефедова — врач-патологоанатом патоморфологической лаборатории ФГБУ «ГНЦДК » Минздрава России, Москва

\section{Конфликт интересов}

Авторы заявляют об отсутствии потенциального конфрликта интересов, требующего раскрытия в данной статье 